\title{
Philosophiques
}

\section{Vers une ontologie « naturalisée " de l'information \\ Paul Young, The Nature of Information, New York, Westport (Conn.) et Londres, Praeger, 1987.}

\section{Normand Lacharité}

Volume 20, numéro 2, automne 1993

Perspectives sur la phénoménologie et l’intentionnalité

URI : https://id.erudit.org/iderudit/027236ar

DOI : https://doi.org/10.7202/027236ar

Aller au sommaire du numéro

Éditeur(s)

Société de philosophie du Québec

ISSN

0316-2923 (imprimé)

1492-1391 (numérique)

Découvrir la revue

Citer cet article

Lacharité, N. (1993). Vers une ontologie « naturalisée » de l'information / Paul

Young, The Nature of Information, New York, Westport (Conn.) et Londres,

Praeger, 1987. Philosophiques, 20(2), 473-483. https://doi.org/10.7202/027236ar d'utilisation que vous pouvez consulter en ligne.

https://apropos.erudit.org/fr/usagers/politique-dutilisation/ 


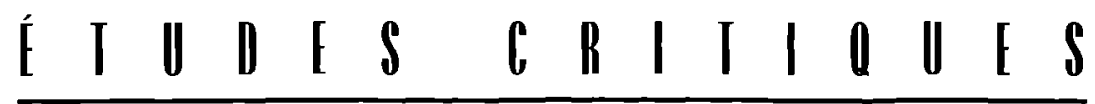

\section{VERS UNE ONIOLOGE « MATURALISEE » DE L'NFORMATION}

\author{
Normand Lacharité
}

Paul Young, The Nature of Information, New York, Westport (Conn.) et Londres, Praeger, 1987.

Ce petit livre est à la fois un essai philosophique et un ouvrage de vulgarisation scientifique; côté philosophique, il expose-et reformule de multiples fois - une thèse personnelle, à caractère ontologique, sur la nature de l'information ; côté vulgarisation, il expose, dans un discours et une langue de type reportage, des fragments de théories scientifiques ordonnés à montrer que la thèse philosophique non seulement est en accord avec les vues de certains savants bien cotés mais encore reçoit de ces vues un degré de plausibilité èlevé.

Le problème qui fournit le contexte d'ensemble est celui de la nature du lien cerveau-pensée, ou cerveau-esprit, et c'est dans ce contexte qu'est soulevée, à titre de sous-problème du précédent, la question de savoir si une certaine définition de l'information et des processus informationnels, définition formulée en termes philosophiques, n'offre pas la base ou la condition de possibilité d'un modèle adéquat du mécanisme selon lequel fonctionne la relation cerveau-esprit. Dans ce qui suit, je décrirai sommairement le contenu du livre en respectant son ordre de composition; puis, je ferai quelques commentaires évaluatifs.

Il est de nos jours question d'information dans la plupart des sciences de la nature et des sciences sociales ou humaines ; c'est en étayant cette affirmation par de nombreux exemples que l'A. présente une partie du contexte dans lequel il va situer sa démarche. L'autre partie du contexte est idéologique ou philosophique : parmi ceux qui font usage du terme « information », certains conçoivent l'information comme quelque chose d'entièrement définissable en termes des caractéristiques de l'énergie-matière, alors que d'autres semblent y voir quelque chose d'un ordre différent, plus abstrait peut-être, quelque chose en tout cas de non entièrement réductible aux propriétés de l'énergie-matière. Cette dernière position permet, suggère, ou parfois même entend justifier, un dualisme ontologique qui pose des entités spirituelles d'une sorte ou d'une 
autre en plus des entités matérielles et qui, pour cette raison, s'oppose plus ou moins radicalement au monisme matérialiste que présuppose et défend la première conception.

L'A. nous annonce clairement qu'il veut montrer :

I) que le concept d'information est entièrement et adéquatement définissable en termes de propriétés de l'énergie-matière ;

2) que la définition proposée par lui est suggérée par, ou tout au moins compatible avec, des fragments bien cotés de la pensée scientifique contemporaine dans les disciplines physico-chimiques, biologiques et psychologiques ;

3) que la définition proposée par lui ouvre des voies de recherche prometteuses, pour ce qui est de la solution des problemes traditionnels concernant la nature de la pensée. IPour fixer les idées, anticipons un peu et notons que l'A. utilisera souvent la typologie quadripartite suivante des actes par lesquels la pensée se manifeste: «cognitions (qui incluent les actes de sensation et les actes de perception), « emotions », « volitions » et « consciousness ». Cette typologie, arbitraire peut-être, est utilisée par beaucoup d'auteurs, a l'avantage de se trouver proche des catégorisations du sens commun - plus son niveau de théoricité est bas, moins elle est sensible aux variations des contextes théoriques - et, finalement, est pédagogiquement fort utile.]

La première étape de la démarche consiste à montrer que l'information se matérialise dans des caractéristiques de forme (ou si l'on veut : dans des caractéristiques du type "forme") : « [information isl embodied in thel shape, configuration, conformation, or structural (form) characteristics $》(\mathrm{p}$. I 7 ), ou encore : « linl the patterning characteristics » des divers systèmes impliqués dans les processus de transmission d'information. On notera au passage que l'information n'est définissable que dans des contextes de processus, que ces processus concernent nécessairement des interactions, et qu'il n'y a d'information repérable que transmise ou considéree comme transmissible. Autre formulation de la première thèse :

[...] the information is embodied entirely in form characteristics of the electrical, chemical, and mechanical components of the systems involved (p. 27).

La suite de la démarche consiste à fournir la définition du concept de forme ; conformément aux contraintes acceptées par l'A. depuis le début, cette définition devra être formulée exclusivement en termes de masse et d' énergie et devra être suffisamment générale pour s'appliquer convenablement et uniformément dans les différents contextes théoriques oủ s'emploient déjà le terme de « forme » et la terminologie afférente. Procédant selon une approche d'enquête, l'A. signale à notre attention un certain nombre de ces contextes d'emploi (cf. p. 33-44), lesquels sont autant d'exemples soit de modèles théoriques qui, dans le cadre de recherches disciplinaires, décrivent les caractéristiques formelles de leurs domaines d'objets (systèmes) respectifs, soit de phénomènes qui, même du point de vue du sens commun, sont fortement « form dependent »; entre autres : la théorie des champs en physique, et particulièrement en physique quantique relativiste, les modèles des systèmes 
moléculaires en chimie et en biochimie, les descriptions plus ou moins "morphologiques" du système nerveux et finalement les descriptions des « principaux systèmes mentaux (abstraits) élaborés par les êtres humains » (p. 42-43), notamment les langages, les ceuvres d'art, les systèmes de logique et de mathématique. (On notera au passage que l'A. semble reconnaître que les constructions théoriques des neurosciences constituent des témoignages moins éclatants que d'autres en faveur de son point de vue ${ }^{\mathrm{I}}$.)

Mais si l'on reconnaît comme un fait - et c'est la conclusion que l'A. tire de son enquête - qu'un aspect morphologique ou géométrique de l'univers semble jouer un rôle dynamique essentiel dans la détermination de l'identité et du comportement de tous les objets et processus, on n'a pas pour autant formulé une définition ontologiquement correcte de la forme. Pour en formuler une, il faudra, selon l'A., soit trancher, soit dépasser « le grand schisme qui au cours de l'histoire a divisé l'opinion et l'analyse quant à savoir si la forme est une entité idéale, abstraite, non physique ou métaphysique, peut-être universelle qui de quelque façon agit sur la matière et s'apparente à l'essence même ou à l'âme d'une chose, ou bien si la forme est un phénomène entièrement physique ou matériel » (p. 45) ${ }^{2}$.

Cest « le phénomène des relations » (p. 47, 49, etc.), entendu au sens d'ensemble ou système de relations entre des événements de type masse-énergie, qui va fournir la clé d'une définition de la forme en termes de masse-énergie. Pour décourager une interprétation purement mathématisante de cet «ensemble de relations », l'A. explicite sa conception de la réalité dont cet ensemble de relations est la manifestation:

[...] lwe interpret] the fabric of the space-time continuum as a plenum (full), rather than a vacuum or void (empty) - that is, as a wholly

I. «There is no doubt that the most essential aspects of the operation of neurons and nervous systems with respect to information flow are form dependent, yet form, as such, is not now widely studied in contemporary neurascience, with the exception of dymamic pattem theory, which examines dynamic (i.e., dissipativel as opposed to static form phenomenon relevant to nervous system functioning. » (Paul Young, p. 42)

2. En deux paragraphes ( 3 et 4 de la p. 45), l'A. fait une association curieuse entre le débat sur la nature de la forme, tel qu'il vient de l'évoquer - c'est alors un débat entre philosophes -, et un autre dèbat, cette fois entre scientifiques du vingtième siècle. L'association est la suivante : « Among twentieth-century scientists, the abstract/ physical duality remains, but the issue seems to have resolved itself into how each person views the nature of the fields that comprise the spacetime contimum. » Or cet autre débat concerne " the question of whether the primary variables are particles or relations, whether the laws of nature are concemed more directly with substance or with form, whether the universe is basically atomistic or morphological. » Icitation du biologiste Edmund W. Sinottl; l'autre débat peut se décrire aussi comme un débat concernant la nature du mouvement, d'après une thèse que l'A. impute à Piaget et qu'il énonce, la prenant à son compte, dans les termes suivants : « ou bien la physique d'un univers matériel (de type masse-énergie) détermine la géométrie de l'espace-temps, ou bien la "géométrie pure" de l'espace vide détermine les mouvements physiques des événements et systèmes de type masse-énergie. » (p. 46) Je dis que l'association entre le premier débat et le deuxième est curieuse (l'association marquée par le verbe « seems to have resolved itself into s), parce que le premier débat en est un dans lequel l'A. va soutenir qu'il faut prendre parti - et il militera pour la conception matérialiste de la forme - alors que les deux positions du deuxième dëbat vont être compatibles avec la thèse de l'A. et vont être admises par l'A.! 
mass-energy system out of which all particles and processes are created, a continuum whose background is real, albeit unavailable at present. We can then reason as follows : Every set or system of relations between events in the physical universe is the manifestation of all the known and possible mass-energy laws applicable to that region of space at which such events occur. In other words, for every set of relations in the universe, there exists an aggregate of all the laws of space-time (known and unknown), which are its essential ingredients and control factors. More simply still : All sets or systems of relations in the universe are the physical manifestations of all applicable mass-energy laws or principles. (p. $\left.5^{1}\right)^{3}$ (Les italiques sont dans le texte original.)

Ces préalables ontologiques importants sont alors suivis de la définition de la forme:

Every set or system of relations in the mass-energy universe constitutes a form of the universe, whether or not distinguishable as such to a given observer (p. 52).

La troisième partie du livre sera consacrée à deux tâches : a) élaborer la définition de l'information ou, plus précisément, la définition du flux informationnel sur la base de la notion de forme, et autres notions connexes, posées dans la partie précédente ; b) caractériser l'aspect sémantique de l'information, c'est-à-dire l'information en tant que sens.

Pour caractériser le flux informationnel, l'A. utilise la distinction (introduite déjà depuis la page 53 de la deuxième partie) entre les deux modes de manifestation primaires du continuum spatio-temporel (appelé aussi « continuum masse-énergie ») : le mode énergétique ou cinétique lkineticl qui concerne ce que nous nommons mouvement, flux, force, travail, puissance, ainsi de suite, et le mode morphologique or géométrique, qui concerne ce que nous nommons structure, arrangement, ordre, organisation, pattern ou forme. Les flux ou processus informationnels sont des transferts de caractéristiques formelles ( $«$ morphiques » serait moins ambigu ici ; l'A. dit « form characteristics ») dans lesquels la composante morphologique du transfert apparait plus déterminante que la composante énergétique eu égard justement à la préservation de la forme ${ }^{4}$. Après avoir présenté et commenté des exemples d'interaction définis sur des systèmes respectivement physiques, chimiques et biologiques, l'A. arrive à deux formulations un peu générales de sa thèse concernant la nature des processus informationnels (les deux formulations citées

3. Le paragraphe qui suit est également intèressant par sa densité et sa force de synthèse : «Using this characterization, all universal events can be understood as complexes of physical (mass-ener gy) relations governed by relevant laws: One set of mass-energy events may be related in such a way as to be expressed as a stringor particle, another as a wave or wormhole, another as a force of interaction, others as molecules, cells, and so forth; but all these phenomena can be viewed most fundamentally as consisting of complexes of lauful relations between mass-energy events. We are now in a position to propose a wholly mass-energy definition of form. » (P. 5) Dans l'idèe qu'une particule ou une cellule est une expression d'un ensemble de relations entre événements, on voit apparaître une manière de penser et de parler qui évoque certaines thèses spinozistes. Les deux paragraphes que je viens de citer (p. $5^{I}$ ) sont désignés par l'A. lui-même comme « the core of this inquiry ». 
ci-dessous sont celles qui me paraissent ressembler le plus à des énoncésdéfinitions) :

We can conclude that any set of mass-energy events or relations in which, predominantly, mass-energy forms are directly moved in space-time, that is, without involving transfer of form characteristics to another system, or in which forms are created and/or destroyed (kinetics), can be described as an energetic process ; and any set of relations in which forms of form characteristics are transferred from their original mass-energy state to at least one other mass-energy system and are embodied in changes in some or all of the form characteristics of the recipient system, can be characterized as an information process. At its most fundamental level, information flow can be defined as a relational-morphological, mass-energy activity involving representational (symbolic) form transfers between two or more mass-energy systems, a flow of form (p. 66).

[...] information processes $[. .$.$] should be characterized as mass-energy events$ in which sets of relations are preserved in space-time and are transferred (flow) to at least one other mass-energy system, form characteristics coming to represent the identity of other form characteristics (p. 6g).

Si l'on me permet de réduire, pour les fins du présent résumé, la théorie de l'information de l'A. à deux thèses principales, la thèse énoncée dans les deux citations précédentes constitue le premier volet de ladite théorie. Le deuxième volet est centré sur la thèse de la résonance. Cette thèse audacieuse, surprenante et incertaine, complète l'ossature de la théorie de l'information présentée par l'A.

La question de départ est la suivante:

What is the meaning, value, or significance of information to a massenergy system? In other words, what is it that generates meaningfulness in the flow of forms between mass-energy systems? (p. 78 )

Does there exist a mass-energy phenomenon or process that can explain how something we call meaningfulness or significance occurs in the form manipulating activities of mass-energy systems? (p. 79)

Profitant de la large polysémie des termes « meaning», « value», « significance » et « meaningfulness », l'A. va développer ses thèses dans un discours dont la rhétorique a ceci d'étrange : elle se présente comme accommodant avec une égale ferveur aussi bien l'acception spécialisée selon laquelle sens et valeur relèvent d'un contexte et d'une activité exclusivement humains que l'acception largissime et largement métaphorique selon laquelle même " l'information matérialisée dans la structure de type ADN a une signification pour les molécules de ARN » (p. 78). Ceux qui comme moi se sont habitués à

4. $\quad$ Infornation processes can be seen as morphological events in which the energetic characteristics are secondary to the preservation and flow of sets of mass-energy relations (forms). 》 (p. 6r) « Information flow, as a flow of form characteristics or set of mass-energy relations, must be seen in all cases to constitute a flow of mass-energy, but a flow in which the form characteristics are the primary ingredient, the energetic events being merely the substrate over which the flow of form characteristics takes place. » (p. 6I) Ces façons de parler ne conceptualisent aucunement la sorte de critères qui sera pertinente et efficace lorsqu'il s'agira de décider si telles caractéristiques du flux sont "primary» ou "secondary". 
considérer comme importante la distinction entre information (tout court) et information sémantique seront un peu interloqués.

La dernière question citée est immédiatement suivie de sa réponse:

The answer is that the mechanical phenomenon of resonance not only provides the necessary explanatory power, but may be the only mass-energy process that can provide such an understanding. Mass-energy forms resonate with one another, the results of their interactions generating new patterns (new energy and information flows), which are the meaning of the information to them. This position has been taken by Thom, who proposes that all information processes can be understood as involving. by resonance, the spatial duplication of forms (p. $79-80$ ).

et Young de citer Thom:

[...] if the source $S$ and receptor $R$ are two identical, symmetrically coupled oscillators, and $\mathrm{S}$ is excited in eigenstate $a, \mathrm{R}$ will also be excited in the same eigenstate; after waiting for the effects of $a$ to die away in R. eigenstate $b$ can be transmitted and so on. (René Thom. Structural Stability and Morphogenesis, Reading (Mass.), W. A. Benjamin, I975 ; p. 145).

Young cite d'autres passages de Thom et certains de ces passages laissent penser que Thom identifie « significance » et « information » et que l'activité de résonance lui sert à distinguer un processus informationnel d'un processus non-informationnel ; ce qui soulève la question : lorsque Young utilise la résonance comme condition de possibilité (et peut-être même comme cause ?) de l'apparition du sens de l'information, fait-il de l'idée de résonance le même usage que Thom, ou bien transpose-t-il une idée de manière à lui faire jouer un autre rôle dans la théorie, éventuellement dans une autre théorie?

Outre qu'il nous renvoie à Thom pour les explications théoriques et les exemples, Young n'offre que deux arguments en faveur de sa thèse de la résonance : l'un est l'argument du principe de parsimonie (le rasoir d'Occam) l'autre tient dans les prémisses suivantes : (Majeure) «Virtually all mass-energy objects and systems (... possess vibratory characteristics 》 (p. 80) ; « Most mass-energy systems, but particularly biological ones, possess large numbers of vibratory or oscillatory patterns of behavior. » (p. 8I). (Mineure) «In all these cases, the behavior of an oscillating system can be affected, that is, driven, damped, or otherwise influenced, by an oscillatory pattern in greater or lesser degrees of harmony. » (p. 8I)

Voilà donc un phénomène relativement particulier (particulier, même si on admet déjà qu'il ne se manifeste pas seulement en acoustique...) promu au rang de principe universel de la nature, au rang d'axiome de la théorie des processus informationnels. L'examen ultérieur de la thèse de la résonance, et du problème auquel elle est censée répondre nécessitera qu'on établisse avec un peu plus de fermeté s'il est bien vrai que seuls des systèmes capables de vivrations, seuls des oscillateurs, peuvent échanger entre eux de l'information, et $s^{\prime} i l$ est bien vrai que la résonance est la seule relation par laquelle un système capable de vibrations exerce jamais des effets sur un autre tel système.

La quatrième et dernière partie importante de l'ouvrage de Paul Young s' intitule « Mind ». Dans cette partie plus développée que les autres (elle couvre 6I pages ; les trois précédentes font 84 pages), l'A. applique à la description-interprétation de l'activité dite mentale les thèses et le vocabulaire de l'ontologie qu'il vient d'élaborer. C'est donc cette partie qui doit livrer la marchandise, qui doit montrer si les définitions et les thèses nomiques-naturalistes posées 
précédemment tiennent leurs promesses. Dans le présent compte rendu, je ne porterai pas un jugement net ; d'une part, je trouve admirable et fort intéressant de voir décrire la formation des concepts, la genèse des émotions et sentiments, l'émergence de la conscience et de la conscience de soi, et finalement la production des volitions (ou intentions d'agir) dans un langage qui mobilise maximalement les modèles scientifiques existants et qui s'efforce courageusement d'honorer ses engagements ontologiques matérialistes anti-substantialistes, tant par fidélité que par cohérence ; d'autre part, l'écart entre l'objectif visé et l'étape réalisée est trop voyant, même aux yeux de l'A., pour qu'aucune forme, même modeste, de triomphalisme soit de mise; il convient au contraire de laisser s'exprimer encore bien des insatisfactions et de tenter d'y répondre comme à autant de problèmes qu'on est content d'avoir suscités.

Comme il serait trop long de résumer avec un peu de spécificité les thèses que propose l'A. pour chacun des aspects de l'activité mentale sur lesquels il se prononce, je vais donner deux exemples : un exemple de la manière dont les recherches expérimentales sont utilisées, et un exemple de la manière dont les thèses sont formulées.

En ce qui concerne les émotions, l'A. ne va guère plus loin que leur appliquer sa thèse générale concernant la nature des processus informationnels :

Emotions can be seen as specific forms of patterned activity in any of a variety of neural structures, and can be interpreted as feeling states of the system, expressed as information and energy flow of characteristic classes (p. 98).

Cette fois, la base empirique invoquée à l'appui de la thèse tient dans les résultats obtenus par Manfred clynes, auteur de Sentics: The Touch of the Emotions. Young ne décrit pas le « sentographe » utilisé par Clynes pour détecter, via une reaction neurophysiologique mesurable survenant au doigt, l'occurrence et la spécificité des sept états émotionnels qu'il a êtudiẻs ; mais il résume les résultats de Clynes : les enregistrements graphiques ont montré des “formes » lessentic forms] propres à chaque état émotionnel, formes «essentiellement équivalentes non seulement pour tous les individus d'un groupe expérimental donné mais encore pour des groupes différant entre eux par la culture, tels que des Mexicains, des Japonais, des Balinais et des Américains. » (p. 97). Young assume la conclusion que Clynes tirait : « la production d'ètats émotionnels chez les humains est un processus à la fois mû par une forme et génétiquement contrôlé » (p. 97).

L'exemple par lequel je veux illustrer le type de discours qu'engendre l'application des postulats ontologiques est tiré de la dernière section de la partie 4. section consacrée à la « Volition »:

What goes on in a living organism during acts of conscious willing or intentionality? The idea proposed here is that shifting arrangements of cell-group excitations generate a complex or matrix of resonant electrical patterns that operate as a feedback and control mechanism. This matrix, driven by and interacting with the underlying substrate, is able to access and coordinate the system's entire information field by dynamic directional shifts in information flow, producing activation of groups of cells in specific patterns, thereby enabling both control functions and conscious awareness to be generated, all in millisecond time periods. A volitional act is a 
selective or ditectional activation of specific informational pathways, an expression of the organism's entire identity at a given moment.

Such a mechanism provides an explanation for the astonishing speed and fluidity with which an organism can undergo shifts in its modes of activity. [...] I can go from catching a baseball, to eating a sandwich, to writing a book, to tying my shoelaces, all with swift, fluid, seamless transitions, primarily as a result of the ability of my system to have instant access to all its stored, circulating, and arriving information, and the ability to coordinate it all into coherent behavior patterns (p. 142-143).

Si la thèse énoncée dans le premier paragraphe de la citation constitue pour l'A. une «explication», c'est une explication d'un genre bien spécial. D’abord, elle est peu spécifique; de fait, avec le même vocabulaire et les mêmes hypothèses, l'A. nous a donné une interprétation des autres aspects de l'activité mentale et les similitudes sont si grandes d'un thème à l'autre que le lecteur finit par avoir l'impression que les formules de base sont des passe-partout ; l'idée, par exemple, que des excitations locales ont des voies d'accès au substrat global vaut certainement pour la perception, le rappel de souvenirs (aussi bien volontaire qu'accidentel), l'émotion, le sentiment, les actes de production d'une argumentation, etc., à peu près au même titre que pour les volitions.

Cette explication est également très générale, au sens où elle tient surtout dans l'évocation de types de mécanismes plutôt que de mécanismes, ces types étant eux-mêmes élevés dans une hiérarchie peu explicitée de types de types ; il est certain qu'en décrivant des processus comme étant ou comme provoquant des " pattern shifts » on ne risque pas de se tromper beaucoup puisque virtuellement tous les processus tombent sous cette catégorie par l'un ou l'autre de leurs aspects ; même chose pour l'idée suivante : « Multiple codings and recodings of information, from chemical to electrical to anatomical forms and back again, occur continually in nervous systems, with no particular code being necessary for any given item of information. » (P I2I). Et à proportion que l'explication est générale en ce sens, elle consiste davantage à imaginer des formes de mécanismes que des mécanismes spécifiques entre systèmes individués, ces formes étant hautement reproductibles, hautement fonctionnelles (au sens de : indifférentes au médium de leur matérialisation) et hautement « standard » (au sens de : peu différenciées, ritualisées, proches de la formulerecette). Ces traits de l'explication, tels quej'essaie de les relever ici brièvement, n'échappent d'ailleurs pas à l'A. ${ }^{5}$.

Une troisième caractéristique du discours de la quatrième partie, considéré dans sa fonction théorique d'explication, est qu'il n'est pratiquement pas connecté au discours de la « philosophy of mind » qui traite des mêmes

5. Jen veux pour témoin ce passage tiré de la partie consacrée à la « consciousness »: « Since at this stage of our knowledge we are not capable of making any useful distinction between the various forms of neuro-electrical activity for purposes of understanding consciousness, other than restating facts - for example, frequency-coded action potentials are the primary information manipulating mechanisms among neurons, amplitude-coded generator potentials among sensory receptors, and so on - all we can say is that it is as a result of a base of interconnected neurons generating and interacting informationally with a complex of patterned electrical activity that living systems can produce in themselves the sensation of consciousness, self-consciousness, and mind. $\gg($ p. $122-3)$ 
sujets ; aucune connexion non plus avec les théories de l'intentionnalité de la tradition Brentano-Husserl qui sont travaillées aujourd'hui en philosophie analytique. Sont inexistantes également les connexions avec la philosophie du langage, celle qui traite par exemple des structures syntaxiques et sémantiques, des attitudes propositionnelles, des actes de discours en général et des actes illocutoires en particulier.

Cette dernière remarque sur le type d'explication (de l'activité mentale) auquel arrive l'A. en suivant l'approche ontologique informationnelle qu'il a balisée me sert de transition et m'amène à quelques remarques concernant de remarquables absences. Pour un livre qui vise à montrer qu'une théorie des actes mentaux peut être fondée sur une ontologie appropriée de l'information, je trouve remarquable que les problèmes suivants ne soient pas traités :

1) le problème de la spécificité de l'information-par-signes, base du sémantisme propre au langage humain, par rapport aux autres espèces d'information.

2) le problème de la spécificité des réactions intentionnelles d'un système sensible à l'information par rapport à l'ensemble des réactions possibles pensées sous le concept générique de résonance. L'A. ne participe pas au débat « explication par les causes / explication par les raisons ».

3) le problème de l'individuation des unités d'information, lequel est devenu central dans le débat entre les tenants de modèles computationnels "classiques" et les tenants de modèles connexionnistes ( parallel distributed processing »). (Un cerveau opère-t-il sur des « symboles physiques », au sens de Newell, comme le fait un ordinateur? Les éléments syntaxiques d'une proposition qu'un système est en train de traiter sont-ils chacun réalisès dans une forme discriminable, c'est-à-dire dans un ensemble de relations individué sur l'ensemble des relations de relations?).

Je fais l'hypothèse que ces trois problèmes ont des rapports entre eux par le fait qu'ils doivent surgir à un moment ou à un autre dans une problématique de la représentation et que c'est le caractère lacunaire, ou trop limité, de la conception de la représentation mise de l'avant par Young qui se manifeste par ces remarquables absences. La théorie de la représentation exposée dans ce livre me semble lacunaire en ce sens que la relation de représentation n'y est jamais conçue que comme une relation à deux termes sur la base de la relation de codage et elle n'est pas développée assez pour tenir compte de ce qu'a de spécifique l'activité constructrice (considérablement déformatrice, il faut bien le dire) des systèmes capables d'intentionnalité et d'autonomie, ni pour tenir compte des phénomènes de renvoi en vertu desquels le contenu représentationnel n'est pas représentation de ce qui est présent à l'input du système mais représentation de quelque chose qui est absent à l'input, et même, souvent, absent de l'environnement du système (pour modèliser des phénomènes de renvoi, comme ceux, entre autres, propres aux signes linguistiques, il faut, je pense, au moins des relations à quatre termes) ${ }^{6}$. Je reconnais que l'A. complexifie par

6. Le concept de reprèsentation est d'ailleurs introduit à un moment où il n'est même pas question d'interactions impliquant au moins un système vivant Au début de la troisième 
la suite la notion de « représentation primitive » en introduisant une notion comme celle de dépendance des caractéristiques morphiques d'un système (et donc de son identité) à l'égard de son contexte ou « frame of reference » (p. 54-55; $75^{-76)}$; des notions comme celle de complémentarité des formes (p. 69-7I) et de codages multiples (p. I2I); mais rien de cela ne commence encore à suggérer ce qu'ont de spécifique les représentations que des systèmes intentionnels et pensants prétendûment produisent lorsqu'ils croient, espèrent ou doutent (je pense ici à la représentation comme objet d'une attitude propositionnelle), ou, plus généralement, lorsqu'ils parlent.

Aux reproches que je fais présentement, l'A. pourrait aisément répondre, j'imagine, qu'au niveau de généralité auquel il se place, avec le souci ontologique qui est le sien, il n'avait ni l'intention ni l'obligation de fournir un modèle spécifique pour la représentation de contenus conceptuels et propositionnels, et qu'il s'est contenté à bon droit de montrer que sa définition de la représentation comme encodage de formes est compatible avec ce que les recherches scientifiques et le sens commun nous enseignent déjà au sujet des représentations habituellement imputées aux systèmes intentionnels et interprétants, et pourrait être développée de manière à devenir plus spécifique. Ả quoi je dis: il s'agit ici de savoir quel prix on paye pour la généralité dont on se félicite ; je crains qu'à prêter aux atomes une capacité de représenter, on ne s'engage à une conception plutôt naïve de la représentation, sans compter la torsion qu'on inflige au lexème « représentation ».

Le lecteur aura compris, j'espère, que les critiques feutrées que j'adresserais peut-être à l'A., au cours de débats plus détaillés que ceux permis ici, n'entachent pratiquement pas le plaisir considérable que j'ai pris à lire ce livre. Dobord il est écrit dans un style qui, malgré son sérieux, bénéficie des talents journalistiques de l'A. et s'en trouve beaucoup plus alerte que celui des ouvrages habituels - au nombre desquels je ne compte pas ceux de Fodor - de «philosophy of mind» ou de science cognitive (ces derniers étant par contre généralement beaucoup plus rigoureux que Young, pour ce qui est de l'argumentation). Puis le livre, tant par ses notes que par sa bibliographie, est une riche mine de renseignements sur les travaux de sciences cognitives inscrits dans la tradition de la psychologie expérimentale; il mentionne ou cite, également, plusieurs des classiques de la théorie de l'information. Enfin, l'utilité majeure de ce livre, à mon avis, est de rappeler, d'une façon assez efficace parce que la présentation est simplifiée, les principaux problèmes que pose le projet de construire une théorie matérialiste (moniste) des actes mentaux qui tienne compte des données et hypothèses de la physique et de la neurologie. A sa

partie, alors qu'il est question d'interpréter comme un processus informationnel l'absorption d'une énergie de radiation par un atome, l'A. écrit : « In these cases, the changes in atomic patteming that occur in response to inputs (dans ce cas ci : des photons d'une certaine fréquencel can be interpreted as a primitive form of representation or coding, the alterations in excitation pattem of the atom being a representation of the specific energy value fidentity) of the incoming radiation. To some extent, the character or identity of the photon has been transferred, preserved, or represented in the changes in the atom's excitation patterns. This interpretation is supported by the fact that the new, excited, informed state of the atom can enable an observer to know the identity of the photon with which that atom has interacted as a direct function of the atom's altered patteming. 》 (p. 62-3) 
façon, The Nature of Information est un nouveau plaidoyer en faveur de la «naturalisation »-comme ont dit les anglophones, à la suite de Quine - de la théorie de la connaissance.

Département de philosophie

Université du Québec à Montréal 